Jurnal ELTIKOM, Vol. 2 No.1, Juni 2018, Hal 1-8 ISSN 2598-3245 (Print), ISSN 2598-3288 (Online)

Tersedia Online di http://eltikom.poliban.ac.id

\title{
IMPLEMENTASI ALGORITMA APRIORI UNTUK MARKET BASKET ANALYSIS BERBASIS R
}

\author{
Thomas Brian ${ }^{1)}$ dan Ardhi Sanwidi ${ }^{2}$ ) \\ 1) Universitas Trunojoyo Madura \\ ${ }^{2)}$ Universitas Nahdlatul Ulama Blitar \\ e-mail: thomasbrian@trunojoyo.ac.id ${ }^{1}$, ardhisanwidi@unublitar.ac.id ${ }^{2)}$
}

\begin{abstract}
More sales transactions hence required a system to generate important information. This innovation will solve many problems in the field of sales marketing and inventory, because the products that are not so salable if paired properly will increase the value of sales. However, looking for associations requires a complicated process because of the problem of large product combinations let alone if the retail business has thousands of products. Apriori is a data mining algorithm to find relationships between items on market basket analysis. By finding the pattern of sales transactions is expected to increase business value. In the process undertaken in this research is implemented using $R$ with a priori function to process data. It starts from reading the dataset until it finds a recommendation from the system that has been created using the function in $R$. Determine the support, confidence and lift values to find the best itemset for the next sale. Trial that has been done with transaction dataset shows best result on value filter support $=0,1$ confidence $=0,8$ and lift $>1$.
\end{abstract}

Keywords: Apriori, Data Mining, Market Basket Analysis, $R$.

\begin{abstract}
ABSTRAK
Semakin banyak transaksi penjualan maka diperlukan suatu sistem untuk menghasilkan informasi yang penting. Inovasi ini akan banyak memecahkan masalah di bidang sales marketing dan inventory, karena produk yang tidak begitu laku jika dipasangkan dengan tepat akan naik nilai penjualannya. Namun mencari asosiasi membutuhkan proses yang rumit karena masalah kombinasi produk yang besar apalagi jika bisnis ritel tersebut memiliki ribuan produk. Apriori adalah algoritma data mining untuk mencari hubungan antar item pada market basket analysis. Dengan menemukan pola transaksi penjualan maka diharapkan nilai bisnis meningkat. Pada proses yang dilakukan pada penelitian ini diimplementasikan menggunakan $R$ dengan function apriori untuk mengolah data. Dimulai dari pembacaan dataset sampai dengan menemukan rekomendasi dari sistem yang sudah dibuat menggunakan function di R. Menentukan nilai support, confidence dan lift berpengaruh untuk menemukan itemset terbaik untuk penjualan selanjutnya. Uji coba yang sudah dilakukan dengan dataset transaksi menunjukkan hasil terbaik pada filter nilai support $=0,1$ confidence $=0,8$ dan lift $>1$.
\end{abstract}

Kata Kunci: Apriori, Data Mining, Market Basket Analysis, $R$.

\section{PENDAHULUAN}

B ISNIS yang semakin berkembang bisa dipengaruhi banyak faktor seperti inovasi pada produk penjualan. Salah satu inovasi di bidang ritel adalah mencari asosiasi atau hubungan antar item produk sehingga dapat dipaketkan dan dijual bersamaan, memberikan rekomendasi produk kepada seseorang berdasarkan riwayat historis pembelian produk, menyusun rak display, dan menyusun halaman produk e-commerce. Inovasi ini akan banyak memecahkan masalah di bidang sales marketing dan inventory, karena produk yang tidak begitu laku jika dipasangkan dengan tepat akan naik nilai penjualannya. Namun mencari asosiasi membutuhkan proses yang rumit karena masalah kombinasi produk yang besar apalagi jika bisnis ritel tersebut memiliki ribuan produk. Diperlukan algoritma yang mumpuni, dan di dunia data science ini dikenali dengan tipe association rules, dan salah satu yang sangat populer adalah apriori.

Algoritma apriori termasuk jenis aturan asosiasi pada data mining, algoritma apriori yang bertujuan untuk menemukan frequent item sets dijalankan pada sekumpulan data. Analisis apriori didefinisikan suatu proses untuk menemukan semua aturan apriori yang memenuhi syarat minimum untuk support 
dan confidence [1]. Algoritma association rules adalah algoritma yang fokus mengidentifikasi hubungan yang kuat antar item-item di dalam suatu populasi dataset. Ini sangat penting karena relasi antar item itu biasanya merupakan masalah kombinasi yang bisa berkembang sangat besar, jauh melampaui jumlah item asli. Item adalah produk tunggal yang menjadi bagian dari transaksi, sedangkan Itemset adalah kombinasi produk yang terdapat pada suatu transaksi. Penelitian sebelumnya yang dilakukan oleh Sandi F. R. tentang algoritma apriori untuk analisis keranjang nelanja pada data transaksi penjualan menjelaskan pola analisis association rules yang ditemukan dapat digunakan sebagai penunjang keputusan manajer dalam mengelola aktifitas perusahaannya [2]. Hasil penerapan association rules oleh Winda A. dengan algoritma apriori menggunakan minimum support $30 \%$ dan minimum confidence $80 \%$ menghasilkan 4614 rules hubungan antar indikator pada dataset kemiskinan Kabupaten Tanah Laut [3]. Penggunaan variabel fuzzy sebelum penerapan algoritma aprirori diterapkan pada dataset harga saham untuk mengetahui pola pergerakan harga saham antar perusahaan [4]. Dengan demikian penelitian ini akan mencoba mengimplementasikan algoritma apriori untuk market basket analysis. Sedangkan dataset yang digunakan adalah contoh data penjualan yang diperoleh dari http://academy.dqlab.id/dataset/data_transaksi.txt. Tujuan dari penelitian ini difokuskan pada market basket analysis untuk menemukan pola unik dari sebuah dataset transaksi.

\section{METODE PENELITIAN}

Pada penelitian ini dilakukan empat tahapan langkah diantaranya: pengumpulan data, transformasi data, implementasi algoritma apriori dan evaluasi hasilnya sebagaimana ditunjukkan pada Gambar 1.

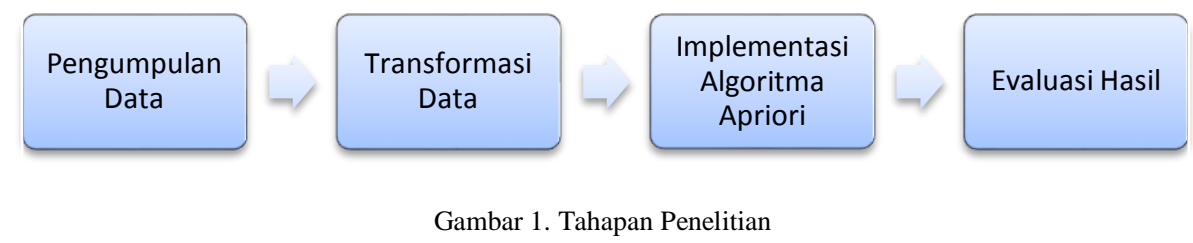

Langkah awal dari data yang dikumpulkan adalah pengumpulan data transaksi dan barang-barang yang dibeli pada setiap transaksi tersebut. Langkah kedua dilakukan transformasi data untuk pengubahan data transaksi yang telah terkumpul menjadi format data standar untuk proses pembacaan data dengan algoritma apriori. Pada Tabel 1, dapat dilihat pola hasil pembacaan transaksi penjualan. "Kode Transaksi" adalah nomor struk dan "Item" adalah item yang dibeli.

TABEL I

TRANSAKSI PENJUALAN

\begin{tabular}{cl}
\multicolumn{2}{c}{ TRANSAKSI PENJUALAN } \\
\hline \hline Kode & \multicolumn{1}{c}{ Item } \\
Transaksi & \\
\hline$\# 01$ & Teh Celup \\
$\# 01$ & Sirup \\
$\# 01$ & Pet Food \\
$\# 02$ & Teh Celup \\
$\# 02$ & Gula \\
$\# 03$ & Sirup \\
$\# 03$ & Pet Food \\
$\# 04$ & Teh Celup \\
$\# 04$ & Sirup \\
$\# 05$ & Teh Celup \\
$\# 05$ & Sirup \\
$\# 05$ & Gula \\
$\# 06$ & Teh Celup \\
$\# 06$ & Pet Food \\
$\# 07$ & Teh Celup \\
$\# 07$ & Sirup \\
$\# 07$ & Pet Food \\
$\# 08$ & Teh Celup \\
$\# 09$ & Teh Celup \\
$\# 09$ & Gula \\
$\# 10$ & Sirup \\
$\# 10$ & Pet Food \\
$\# 10$ & Gula \\
\hline
\end{tabular}


Transaksi penjualan tersebut disimpan dalam format text file (.txt) yang selanjutnya diubah menjadi data.frame dengan perintah read.csv di $R$. Hasil dari pengubahan ini diberikan pada Gambar 2.

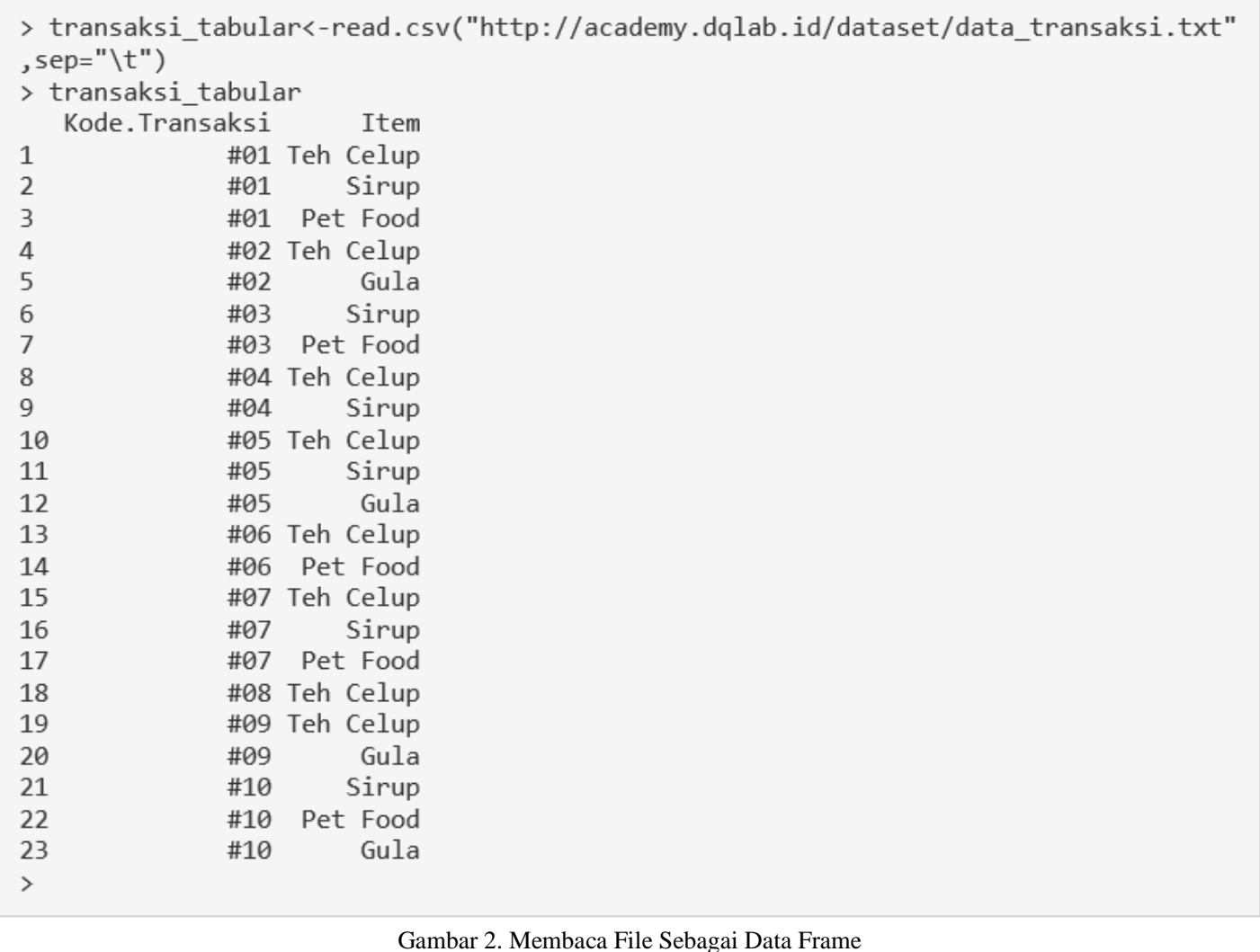

Gambar 2. Membaca File Sebagai Data Frame

Untuk mempermudah dalam pembacaan data transaksi di package $R$ digunakan fungsi read.transactions yang diperlihatkan pada Gambar 3.

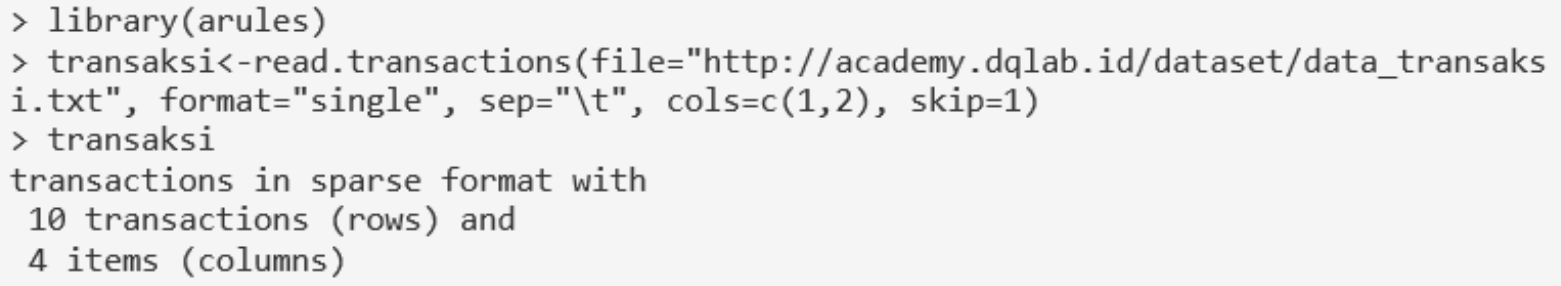

Gambar 3. Fungsi Read Transactions

Item-item yang terdapat pada objek transactions dapat dilihat dengan aksesor @itemInfo seperti pada Gambar 4 dan daftar transaksi menggunakan@itemsetInfo seperti pada Gambar 5.

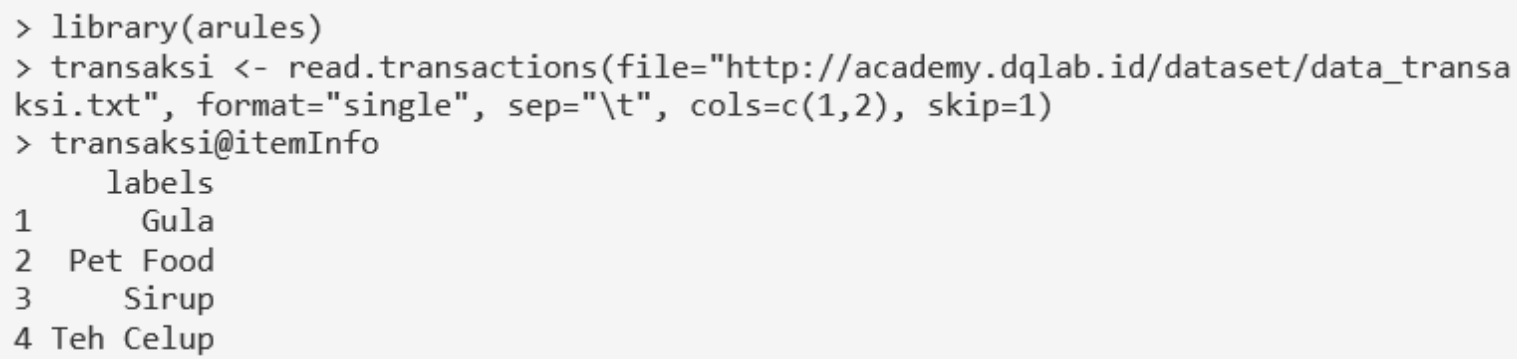




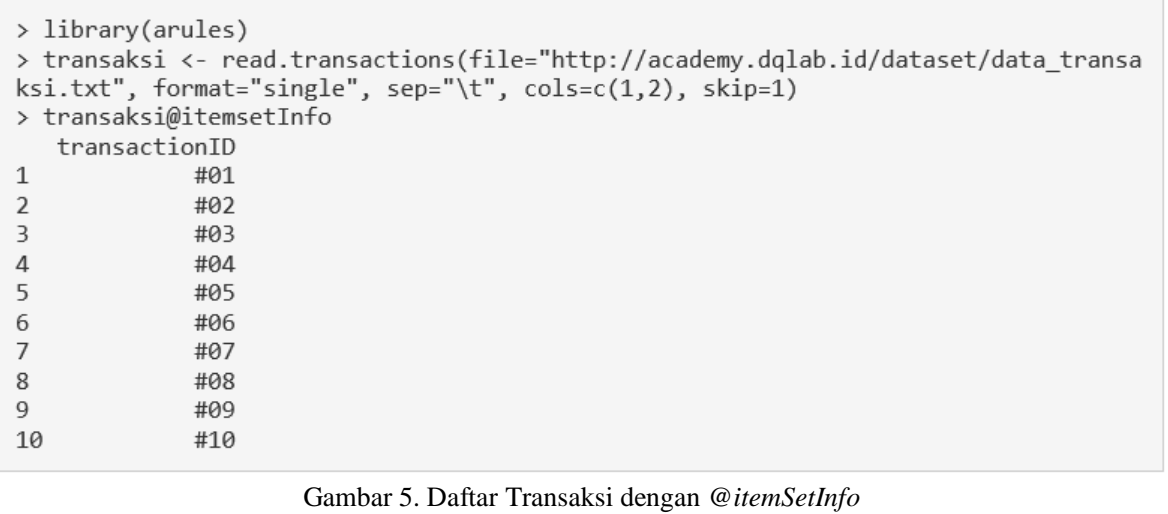

Langkah ketiga, dilakukan implementasi algoritma apriori dengan menggunakan bahasa pemrograman R. Beberapa tahapan dalam penerapan association rules dengan algoritma apriori ini adalah dengan:

1. Menentukan nilai minimum support dan minimum confidence, dan

2. Menentukan nilai lift terbaik untuk menemukan kombinasi itemset frekuensi tinggi.

Langkah terakhir program yang telah dikembangkan adalah mengolah data yang sudah ada. Pada tahap akhir ini dilakukan evaluasi hasil pengolahan data dengan program yang telah dikembangkan.

\section{HASIL DAN PEMBAHASAN}

Dataset yang digunakan berformat .txt yang kemudian dibaca menggunakan RStudio. Dari hasil yang diperoleh, terdapat 10 transaksi dengan 4 item (Gula, Pet Food, Sirup dan Teh Celup). Apabila dijalankan dengan perintah read.transaction dan dibentuk menjadi sebuah matriks pada $\mathrm{R}$ maka diperoleh sebagaimana ditunjukkan pada Gambar 6.

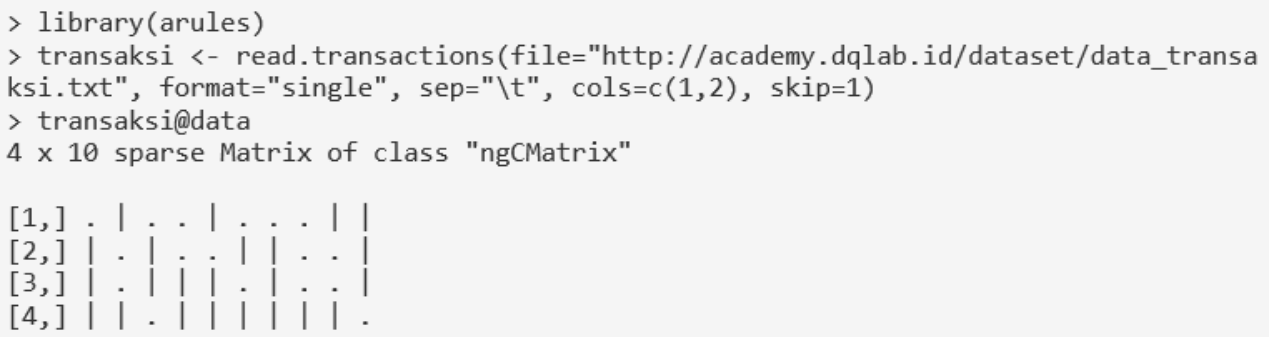

Gambar 6. Pembacaan Dataset di R

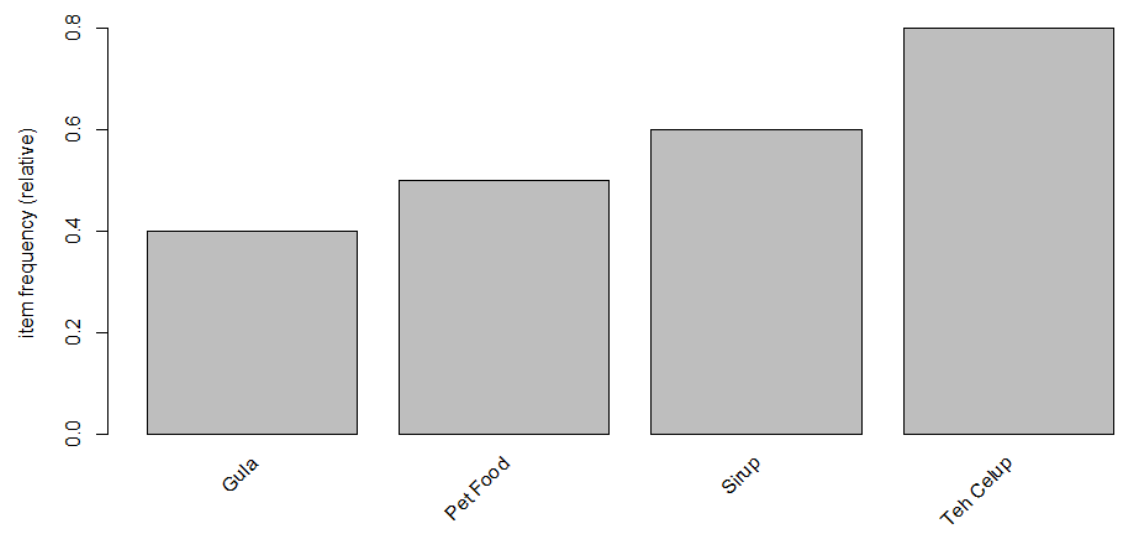

Gambar 7. Grafik Item Frequency 
Setelah dilakukan pembacaan dataset transaksi, selanjutnya menganalisa pola kombinasi dari itemset beserta detil dari association rules menggunakan function apriori. Makna " 4 x 10" berarti bahwa terdapat 4 item dan 10 transaksi. Selanjutnya simbol [1,] sampai dengan [4,] adalah baris item. Rangkaian simbol tanda titik (".") dan garis lurus ("") menandakan bahwa item tidak ada (tanda titik) dan item ada (garis lurus) untuk posisi transaksi ke-n. Selain dengan visualisasi matrik sederhana seperti pada Gambar 6, cara lain yang dapat dilakukan untuk melihat distribusi transaksi dari tiap item adalah dalam bentuk grafik, yakni dengan menggunakan function itemFrequencyPlot dimana hasilnya dapat ditunjukkan pada Gambar 7.

Hasil lebih detail dapat ditunjukkan seperti Gambar 8 dimana penjelasan masing-masing simbol yang digunakan adalah sebagai berikut: lhs adalah itemset di bagian kiri (left hand side); rhs adalah itemset di bagian kanan (right hand side); support, confidence dan lift adalah berbagai metrik yang digunakan untuk menilai kualitas dari rule yang umumnya semakin besar semakin baik. Sedangkan count adalah jumlah kemunculan itemset gabungan lhs dan rhs pada dataset transaksi.

\begin{tabular}{llllll}
\hline Ihs & rhs & support confidence lift & count \\
[1] \{\} & $\Rightarrow\{$ Teh Celup\} & 0.8 & 0.8 & 1.0000008 \\
[2] $\{$ Pet Food\} & $\Rightarrow\{$ Sirup & 0.4 & 0.8 & 1.3333334 \\
[3] $\{$ Gula,Pet Food $\}$ & $\Rightarrow$ SSirup\} & 0.1 & 1.0 & 1.6666671
\end{tabular}

Gambar 8. Association Rules dengan Function Apriori Tanpa Parameter

Pada Gambar 8, terlihat rule kedua dengan $\{$ Pet Food $\} \Rightarrow\{$ Sirup $\}$ adalah cukup menarik. Apabila rule ini diaplikasikan, maka ada beberapa opsi (pilihan) yang bisa dilakukan, diantaranya yaitu:

- $\quad$ rekomendasikan setiap yang membeli Pet Food dengan Sirup

- $\quad$ rak display Pet Food dan Sirup bisa didekatkan

- $\quad$ Pet Food dan Sirup dipaketkan bersama dan dijual dengan harga khusus.

Dari hasil yang ditunjukkan pada gambar 8 dengan menggunakan function apriori secara default tanpa parameter apapun, dihasilkan tiga rules yang merupakan nilai dari minimum support 0,1 dan minimum confidence 0,8 sebagai filter dari function apriori. Jika parameter minimum support dan confidence masing-masing bernilai 0,1 dan 0,5 maka dihasilkan enam belas (16) rules. Perintah berikut merupakan perintah yang ditulis pada program $\mathrm{R}$ :

apriori (transaksi, parameter $=$ list ( $\operatorname{supp}=0.1$, confidence $=0.5)$ )

Hasil dari perintah ini dapat dilihat pada Gambar 9.

\begin{tabular}{|c|c|c|c|c|c|}
\hline & lhs & rhs & support & confidence & lift \\
\hline [1] & \{\} & $\Rightarrow\{$ Pet Food $\}$ & 0.5 & 0.5000000 & 1.0000000 \\
\hline [2] & \{\} & $\Rightarrow\{$ Sirup $\}$ & 0.6 & 0.6000000 & 1.0000000 \\
\hline [3] & \{\} & $\Rightarrow\{$ Teh Celup $\}$ & 0.8 & 0.8000000 & 1.0000000 \\
\hline [4] & $\{$ Gula $\}$ & $\Rightarrow\{$ Sirup $\}$ & 0.2 & 0.5000000 & 0.8333333 \\
\hline [5] & $\{$ Gula $\}$ & $\Rightarrow\{$ Teh Celup $\}$ & 0.3 & 0.7500000 & 0.9375000 \\
\hline [6] & $\{$ Pet Food $\}$ & $\Rightarrow\{$ Sirup $\}$ & 0.4 & 0.8000000 & 1.3333333 \\
\hline [7] & $\{$ Sirup $\}$ & $\Rightarrow\{$ Pet Food $\}$ & 0.4 & 0.6666667 & 1.3333333 \\
\hline [8] & $\{$ Pet Food $\}$ & $\Rightarrow\{$ Teh Celup $\}$ & 0.3 & 0.6000000 & 0.7500000 \\
\hline [9] & $\{$ Sirup $\}$ & $\Rightarrow\{$ Teh Celup $\}$ & 0.4 & 0.6666667 & 0.8333333 \\
\hline$[10]$ & $\{$ Teh Celup $\}$ & $\Rightarrow\{$ Sirup $\}$ & 0.4 & 0.5000000 & 0.8333333 \\
\hline [11] & $\{$ Gula, Pet Food $\}$ & $\Rightarrow\{$ Sirup $\}$ & 0.1 & 1.0000000 & 1.6666667 \\
\hline$[12]$ & $\{$ Gula,Sirup $\}$ & $\Rightarrow\{$ Pet Food $\}$ & 0.1 & 0.5000000 & 1.0000000 \\
\hline [13] & $\{$ Gula,Sirup $\}$ & $\Rightarrow\{$ Teh Celup $\}$ & 0.1 & 0.5000000 & 0.6250000 \\
\hline [14] & $\{$ Pet Food,Sirup $\}$ & $\Rightarrow\{$ Teh Celup $\}$ & 0.2 & 0.5000000 & 0.6250000 \\
\hline [15] & $\{$ Pet Food, Teh Celup\} & $\Rightarrow\{$ Sirup $\}$ & 0.2 & 0.6666667 & 1.1111111 \\
\hline [16] & $\{$ Sirup, Teh Celup $\}$ & $\Rightarrow\{$ Pet Food $\}$ & 0.2 & 0.5000000 & 1.0000000 \\
\hline
\end{tabular}

Gambar 9. Association Rules dengan Function Apriori Parameter Support $=0,1$ dan Confidence $=0,5$ 
Pada Gambar 9, terdapat 16 jumlah rules yang dihasilkan dimana jumlah ini jauh lebih banyak dibandingkan tanpa menggunakan parameter yang hanya menghasilkan 3 rules (Gambar 8), sehingga terdapat lebih banyak pilihan untuk melakukan filter lhs dan rhs. Untuk menampilkan filter lhs dan rhs yang memiliki item Teh Celup menggunakan perintah berikut:

$$
\text { subset (mba, lhs oin\% "Teh Celup" | rhs \%in\% "Teh Celup") }
$$

Hasil dari perintah ini diberikan pada Gambar 10.

\begin{tabular}{|c|c|c|c|c|c|}
\hline & lhs & rhs & support & confidence & lift \\
\hline [1] & \{\} & $\Rightarrow\{$ Teh Celup $\}$ & 0.8 & 0.8000000 & 1.0000000 \\
\hline [2] & $\{$ Gula $\}$ & $\Rightarrow\{$ Teh Celup $\}$ & 0.3 & 0.7500000 & 0.9375000 \\
\hline [3] & $\{$ Pet Food $\}$ & $\Rightarrow\{$ Teh Celup $\}$ & 0.3 & 0.6000000 & 0.7500000 \\
\hline [4] & $\{$ Sirup $\}$ & $\Rightarrow\{$ Teh Celup $\}$ & 0.4 & 0.6666667 & 0.8333333 \\
\hline [5] & $\{$ Teh Celup $\}$ & $\Rightarrow\{$ Sirup $\}$ & 0.4 & 0.5000000 & 0.8333333 \\
\hline [6] & $\{$ Gula,Sirup $\}$ & $\Rightarrow\{$ Teh Celup $\}$ & 0.1 & 0.5000000 & 0.6250000 \\
\hline [7] & $\{$ Pet Food,Sirup\} & $\Rightarrow\{$ Teh Celup $\}$ & 0.2 & 0.5000000 & 0.6250000 \\
\hline [8] & $\{$ Pet Food,Teh Celup $\}$ & $\Rightarrow\{$ Sirup $\}$ & 0.2 & 0.6666667 & 1.1111111 \\
\hline [9] & $\{$ Sirup, Teh Celup $\}$ & $\Rightarrow\{$ Pet Food $\}$ & 0.2 & 0.5000000 & 1.0000000 \\
\hline
\end{tabular}

Gambar 10. Filter lhs dan rhs yang Memiliki Item Teh Celup

Pada Gambar 10 terdapat sembilan (9) rules sebagai hasil filter dan jika digunakan informasi support, confidence dan lift maka kandidat yang bagus terdapat pada rule ke- 8 dimana nilai lift lebih dari 1. Pada rule ini terdapat ( $\{$ Pet Food, Teh Celup $\} \Rightarrow$ \{Sirup $\}$ ). Untuk melakukan filter terhadap metrik kualitas dari association rules: support, confidence dan lift adalah dengan menggunakan function subset. Function yang sama juga digunakan untuk melakukan filter terhadap lhs dan rhs. Perbedaannya adalah karena nilainya berupa angka, maka untuk ketiga metrik tersebut digunakan operator perbandingan angka. Sebagai contoh, untuk melakukan filter dengan kondisi berikut:

- $\quad$ lhs atau rhs memiliki Teh Celup

- $\quad$ lift di atas 1

maka perintahnya adalah sebagai berikut:

subset (mba, (lhs ino "Teh Celup" | rhs in\% "Teh Celup") \& lift>1)

Hanya terdapat satu (1) rule sebagai hasil filter dan paket produk ini cukup menjanjikan, dimana Teh Celup menjadi komponen dari itemset di lhs. Selengkapnya hasil filter ini dapat ditunjukkan pada Gambar 11.

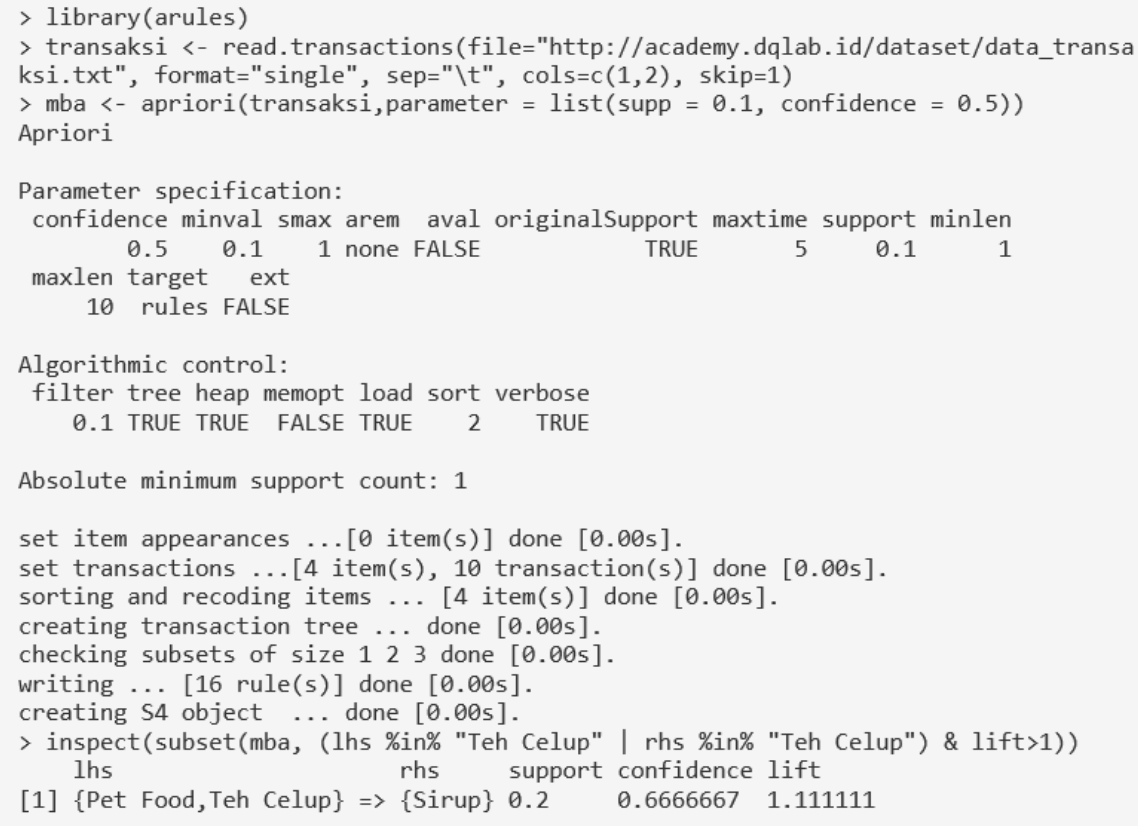

Gambar 11. Filter lhs dan $r h s$ dengan Item Teh Celup dan Lift > 1 
Operator \%in\% yang sebelumnya telah digunakan sudah efektif. Namun operator ini tidak cocok jika ingin melakukan filter itemset dengan logika AND. Artinya seluruh item harus muncul dalam itemset yang terpilih. Untuk keperluan tersebut, digunakan operator \%ain\% sebagaimana berikut:

subset (mba, (lhs oaino c("Pet Food", "Gula")))

Ekspresi ini menjadi kunci untuk membuat rekomendasi. Hasil dari perintah ini ditunjukkan pada Gambar 12.

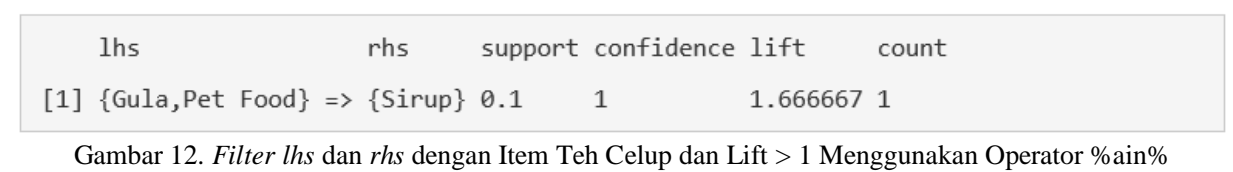

Ketika item semakin banyak, maka diperlukan visualisasi untuk membantu analisa. Jenis visualisasi cukup banyak, contohnya graph yang terdapat pada package arulesViz yaitu suatu package dengan visualisasi khusus untuk association rules. Berikut adalah visualisasi yang dihasilkan dari rules yang telah dilakukan filter dengan lift di atas nilai 1.1 yang diperlihatkan pada Gambar 13.

\section{Graph for 4 rules}

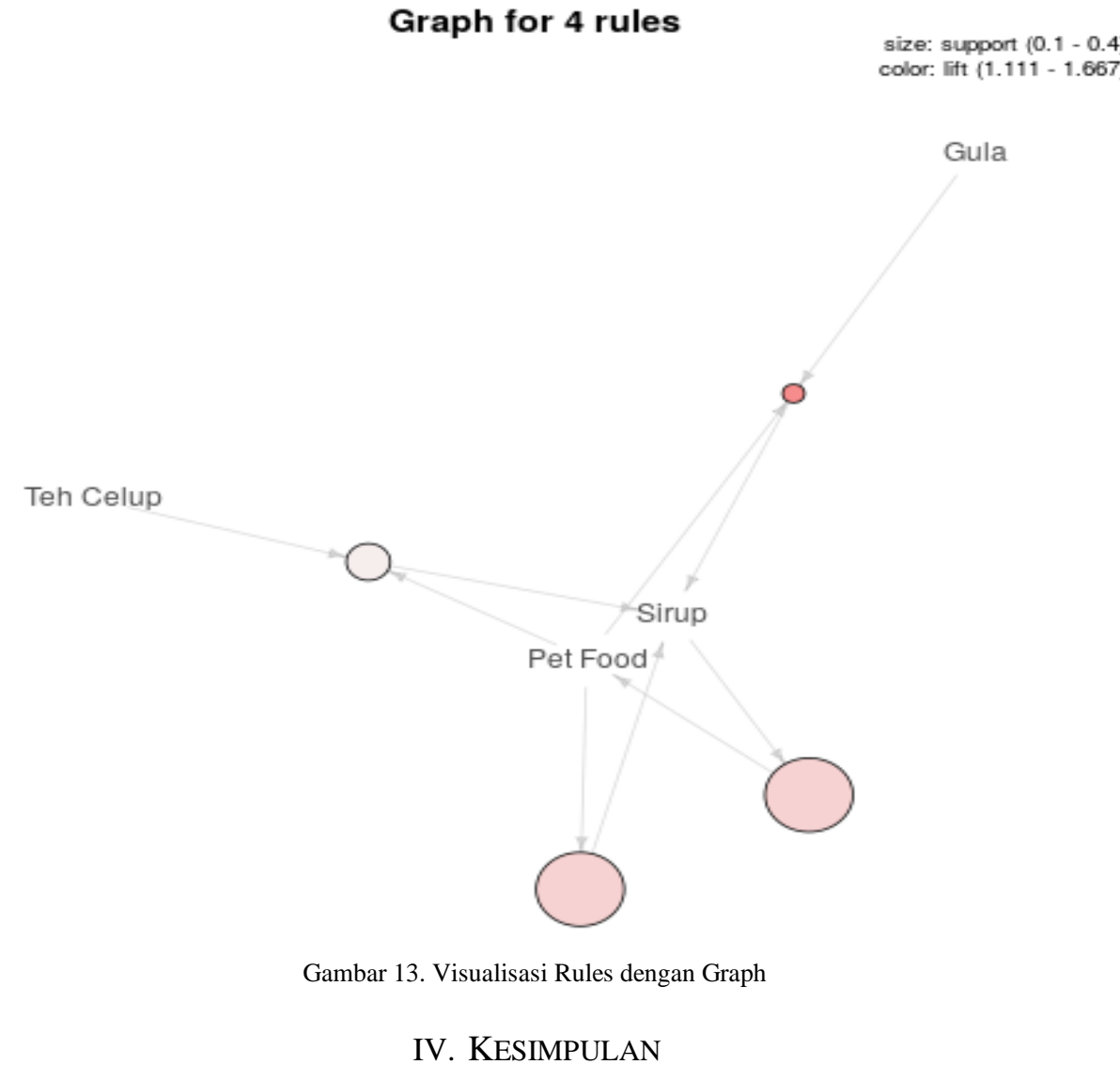

Setelah melalui tahapan pembacaan dataset transaksi, implementasi dan beragam pengujian, dapat diambil beberapa kesimpulan sebagai berikut:

1. Dari hasil pengujian, sistem telah terbukti berhasil mengimplementasikan algoritma apriori untuk MBA (Market Basket Analysis),

2. Hanya terdapat satu (1) rule sebagai hasil filter, dan dengan lift di atas 1 dan support $0,1(10 \%)$. Rule ini bisa dianggap layak untuk meghasilkan rekomendasi item, yaitu Sirup, sehingga orang yang membeli Gula dan Pet Food bisa ditawarkan dengan item Sirup. 


\section{DAFTAR PUSTAKA}

[1] Nursikuwagus, T. Hartono, “Implementasi Algoritma Apriori Untuk Analisis Penjualan Dengan Berbasis Web," Jurnal SIMETRIS, vol. 7, no. 2, hal. 701-706, 2016.

[2] S.F. Rodiyansyah, "Algoritma Apriori untuk Analisis Keranjang Belanja pada Data Transaksi Penjualan,” Infotech Journal, vol. 1, no. $2,2016$.

[3] W. Aprianti, K.A. Hafidz, M.R. Rizani, "Implementasi Association Rules dengan Algoritma Apriori pada Dataset Kemiskinan," Limits Journal, vol. 14, no. 2, hal. 57-67, 2017.

[4] A.A. Arafah, I. Mukhlash, "The Application of Fuzzy Association Rule on Co-Movement Analyze of Indonesian Stock Price," Procedia Computer Science, vol. 59, hal. 235-243, 2015.

[5] J. Han, M. Kamber, Data Mining: Concepts and Techniques, Edisi kedua, San Francisco, CA: Elsevier inc., 2006.

[6] R.T. Vulandari, Data Mining Teori dan Aplikasi Rapidminer, Edisi pertama, Yogyakarta: CV. Gava Media, 2017, hal. 65.

[7] Y. Cohen, J.Y. Cohen, Statistics and Data with R: An applied approach through examples. United Kingdom: John Wiley \& Sons Ltd., 2008.

[8] J.M. Zelle, Python Programming: An Introduction to Computer Science. Version 1.0rc2. Wartburg College Printing Services, 2002.

[9] Hendri, Cepat Mahir Python. 2003, http://www.IlmuKomputer.com.

[10] H.N. Wulandari, N.W. Rahayu, "Pemanfaatan Algoritma Apriori untuk Perancangan Ulang Tata Letak Barang di Toko Busana," Seminar Nasional Aplikasi Teknologi Informasi (SNATI), vol. 1, no. 1, 2014.

[11] S. Susanto, D. Suryadi, Pengantar Data Mining: Menggali Pengetahuan dari Bongkahan Data. Yogyakarta: Andi Offset, 2010. 